\title{
DETERMINATION OF ACRINATHRIN RESIDUES IN HONEY AND BEESWAX
}

\author{
Mária SZERLETICS TÚRI ${ }^{1 *}$ and Enikő SZALAI MÁTRAY ${ }^{2}$ \\ '`József Fodor' National Centre of Public Health, National Institute of Food Hygiene and \\ Nutrition, H-1097 Budapest, Gyáli u. 3/a, Hungary; ${ }^{2}$ Institute for Small Animal Research, \\ Gödöllö, Hungary
}

(Received November 13, 1998; accepted January 11, 1999)

The Asian bee mite (Varroa jacobsoni Oud.) causes variable damage in Hungarian apiaries due to the different and changing conditions. Plastic and wooden strips impregnated with synthetic pyrethroid-type active ingredients show a high efficacy against the mites. These treatments, however, may leave residues in bee products (honey, propolis, wax). After experimental treatment with Gabon PA 92, the levels of active ingredient (acrinathrin) residues were determined in honey and beeswax samples. The analytical results proved that the average concentration of acrinathrin residues was less than $0.01 \mathrm{mg} / \mathrm{kg}$ in honey and less than $0.10 \mathrm{mg} / \mathrm{kg}$ in beeswax. From the food-hygienic point of view it is favourable that the honey did not become 'contaminated' with acrinathrin during the experimental treatment. The analytical results serve as a basis for the registration of this veterinary product in Hungary.

Key words: Bee acaricide, acrinathrin, pyrethroid, residues, Gabon PA 92, honey, beeswax

The continuous damage done by the Asian bee mite (Varroa jacobsoni Oud.) since 1978 made it necessary to hold an international symposium in Prague in 1993 to discuss methods for the control of this parasite. At that symposium different biological, mechanical and chemical tools were presented.

In Hungary, the living conditions of bees, the short distance between apiaries as well as the wandering of bee-keepers make it impossible to eradicate the mite completely. The damage of this parasite varies as a result of the dissimilar and continuously changing conditions. Its presence is, therefore, always presumable and should be considered. At the moment, we cannot protect our colonies either by biological breeding methods (Woyke, 1989; Bienefeld and Pritsch, 1992; Büchler, 1993; Hoffmann, 1993; Rosenkranz et al., 1990) or by applying materials of natural origin (Wallner, 1993). As a complement to other methods,

*Fax: (36 1) 2151545 
the application of synthetic chemicals with different active ingredients is accepted in Hungary (Tóth, 1998).

The prolonged application of these chemicals may lead to the development of resistance (Hillesheim et al., 1996) or cross-resistance (Milani et al., 1995) and to the accumulation of the compounds in beeswax (Wallner, 1997).

Our aim was to find a method providing acceptable protection against the Varroa mite with minimal exposure to chemicals. Therefore, we started experiments with the application of Gabon PA 92 wooden strips. This veterinary product proved to be effective. Our earlier trials (lasting several years) showed that a single treatment performed in autumn was sufficient for maintaining the bee colonies in healthy condition and keeping the number of mites on an acceptably low level.

Consumers are increasingly aware of the hazard posed by the chemical contamination of food. With this in view, an experimental treatment was carried out to determine the levels of acrinathrin residues in apicultural products.

For the first time in August 1994, a comparative experimental treatment was performed in the apiary of the Institute for Small Animal Research to test Gabon PA 92 strips. In this experiment the efficiency of Gabon PA 92 was compared with that of Apistan (with fluvalinate active ingredient) and a home-made wooden plate impregnated with Klartan (also containing fluvalinate). The experiment involved laboratory and open field tests of both brood and adult bees (Szalai et al., 1998).

\section{Materials and methods}

Gabon PA 92 strips contain acrinathrin in a quantity of $1.2-1.7 \mathrm{mg} /$ strip. Figure 1 shows the structure of the active ingredient, which belongs to the group of synthetic pyrethroids.

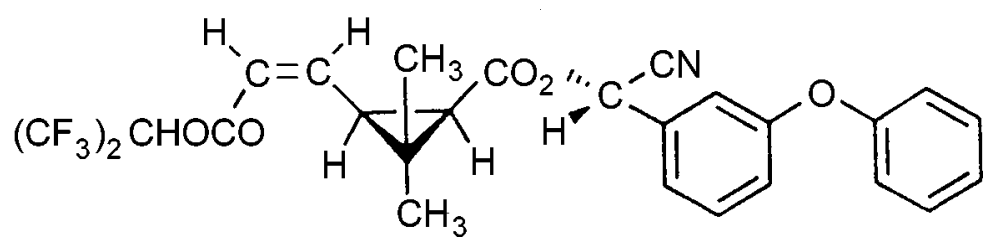

Fig. 1. Structure of acrinathrin. Active ingredient: (S)- $\alpha$-cyano-3-phenoxybenzyl (Z)-(1R,3S)-2,2dimethyl-3-[2-(2,2,2-trifluoro-1-trifluoromethylethoxycarbonyl) vinyl] cyclopropanecarboxylate

(IUPAC)

After a single treatment in 1995 and 1996 respectively, in the spring of 1997 the following experimental treatment was performed. Five bee colonies were treated by hanging 2 GABON PA 92 strips into every beehive for 25 days. 
After this treatment the amount of active ingredient residue in honey and beeswax samples taken from beehives treated with GABON PA 92 was determined.

Two weeks after removing the strips from the treated beehives (at the time of honey extraction) honey and wax samples were taken. Untreated (control) samples were also taken at the same time. To avoid degradation of the active ingredient, the samples were stored at $-18^{\circ} \mathrm{C}$.

The appearance of the lipophilic active ingredient was expected first of all in the beeswax. Therefore, honey and beeswax samples were analysed for residue content separately, according to the sample preparation and analytical method presented in Figs 2 and 3. The analysis consisted of the following stages: sampling, extraction, clean-up, gas chromatographic determination with external standardisation.

Sample preparation was based on the method introduced by Vesely et al. (1995). The acrinathrin residue was determined by gas chromatography with electron capture detection. The parameters of gas chromatography are shown in Table 1.

Parallel to the treated samples we examined control honey and beeswax samples from an untreated beehive and samples spiked with active ingredient. Acrinathrin was added to honey and beeswax in $0.05-5.0 \mathrm{mg} / \mathrm{kg}$ amounts, and subsequently the recovery rates $(\%)$ were determined. The mean recovery rate was $\mathbf{9 6 . 7 \%}$ for honey samples and $\mathbf{8 8 . 3 \%}$ for beeswax samples (Table 2).

\section{Results}

The results are summarised in Table 3. The data represent the means of the results of two parallel measurements each.

Blind studies of the chemicals involved did not show any crosscontamination. Acrinathrin residues were not detected in the extracts of control honey and wax samples, which indicates residue levels of $<0.01 \mathrm{mg} / \mathrm{kg}$ for honey and $<0.10 \mathrm{mg} / \mathrm{kg}$ for beeswax.

\section{Discussion}

The analytical results proved that the residue levels of active ingredient were less than $0.01 \mathrm{mg} / \mathrm{kg}$ in honey and less than $0.10 \mathrm{mg} / \mathrm{kg}$ in beeswax.

From the food-hygienic point of view it is favourable that acrinathrin residues were not detectable in any of the processed honey and wax samples. During the experimental treatment the honey did not become 'contaminated' with acrinathrin. 


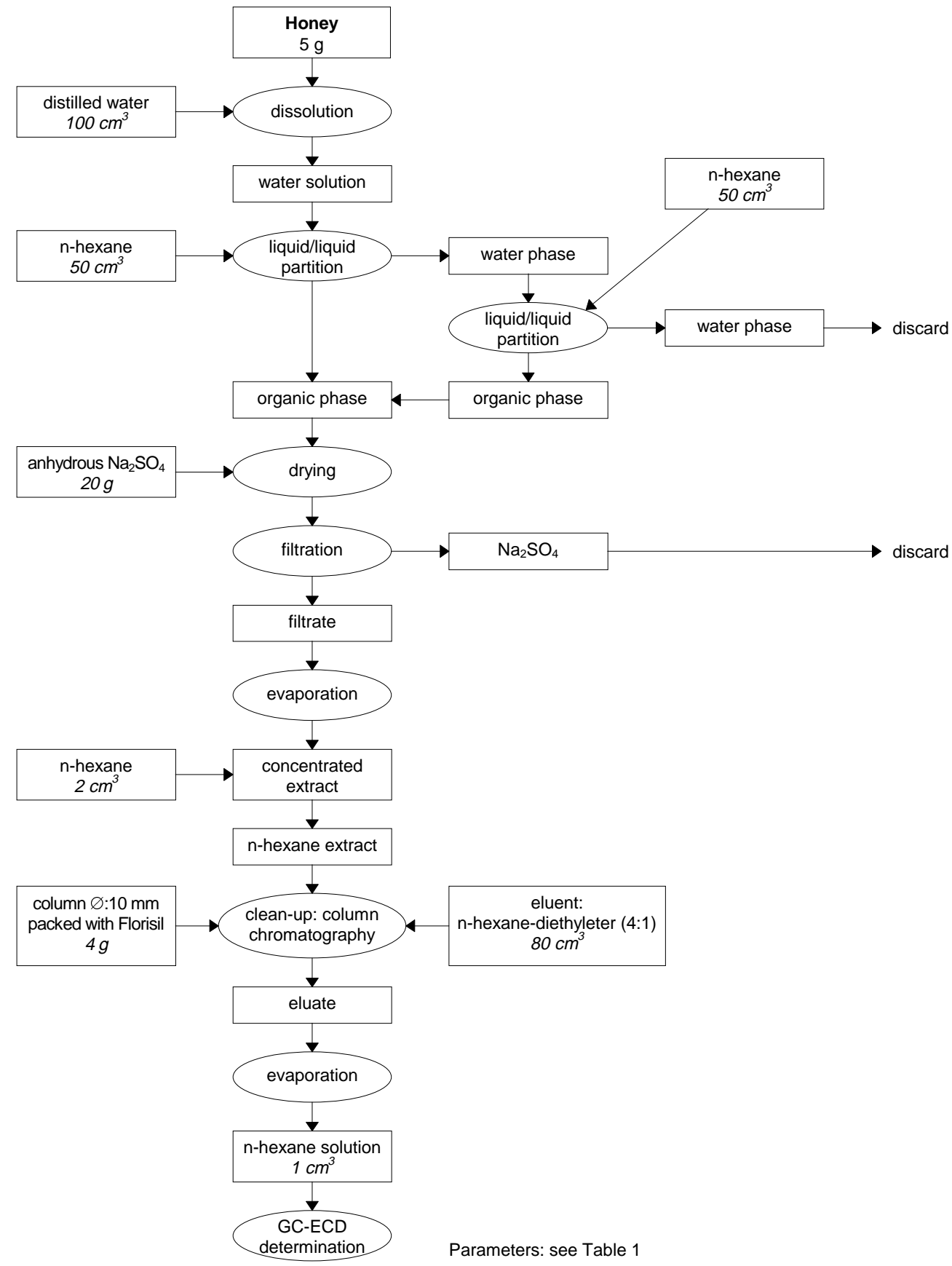

Fig. 2. Analytical method for the determination of acrinathrin residues in honey 


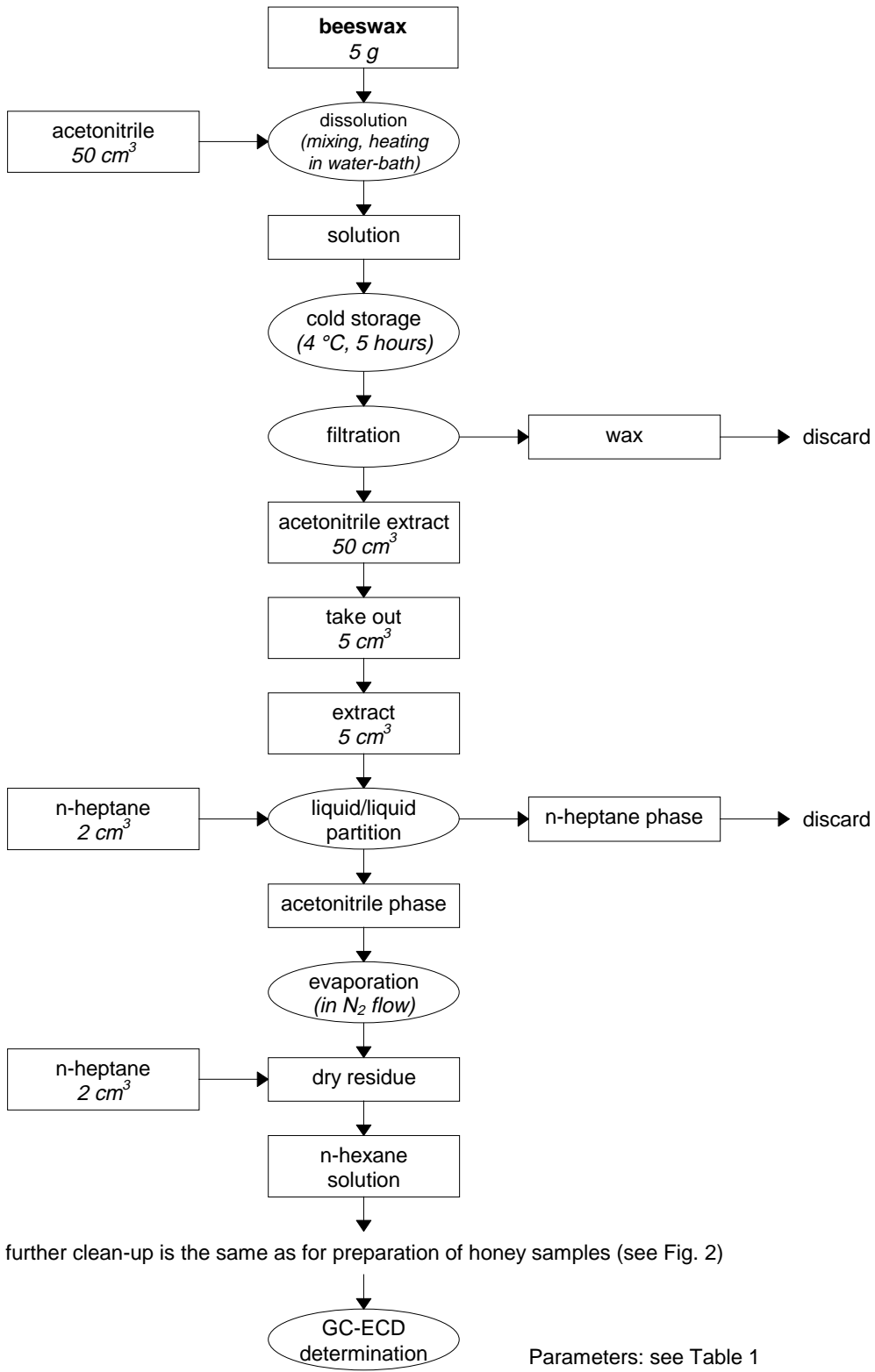

Fig. 3. Analytical method for the determination of acrinathrin residues in beeswax 
Table 1

Parameters of the gas chromatographic determination

\begin{tabular}{|c|c|c|c|}
\hline & \multicolumn{2}{|c|}{ I. For honey extracts } & II. For beeswax extracts \\
\hline Instrument & \multicolumn{2}{|c|}{ Chrompack 9000} & Perkin Elmer Sigma 3B \\
\hline Detector & \multicolumn{2}{|c|}{ ECD (Ni 63) } & ECD (Ni 63) \\
\hline Column & $\begin{array}{c}25 \mathrm{~m} \times 0.32 \mathrm{~mm} \text { i.d. } \varnothing \\
\text { CP Sil PAH CB } \\
\mathrm{d}_{\mathrm{f}}=0.12 \mu \mathrm{m}\end{array}$ & $\begin{array}{c}25 \mathrm{~m} \times 0.32 \mathrm{~mm} \text { i.d. } \varnothing \\
\text { HP Ultra } 1 \\
\mathrm{~d}_{\mathrm{f}}=0.52 \mu \mathrm{m}\end{array}$ & $\begin{array}{c}1 \mathrm{~m} \times 2 \mathrm{~mm} \text { i.d. } \varnothing \text { glass } \\
2 \% \text { OV } 101 / \\
\text { GasChrom Q } \\
100-120 \mathrm{mesh}\end{array}$ \\
\hline Carrier gas & \multicolumn{2}{|c|}{$\begin{array}{l}\text { nitrogen of high purity } \\
3 \mathrm{~cm}^{3} / \mathrm{min}\end{array}$} & $\begin{array}{l}\text { nitrogen of high purity } \\
45 \mathrm{~cm}^{3} / \mathrm{min}\end{array}$ \\
\hline Make-up gas & \multicolumn{2}{|c|}{$\begin{array}{l}\text { nitrogen of high purity } \\
30 \mathrm{~cm}^{3} / \mathrm{min}\end{array}$} & $\begin{array}{l}\text { nitrogen of high purity } \\
30 \mathrm{~cm}^{3} / \mathrm{min}\end{array}$ \\
\hline Split proportion & $5: 1$ & $5: 1$ & - \\
\hline $\begin{array}{l}\text { Temperatures } \\
\text { injector } \\
\text { column } \\
\text { detector }\end{array}$ & $\begin{array}{l}240^{\circ} \mathrm{C} \\
220^{\circ} \mathrm{C} \\
280^{\circ} \mathrm{C}\end{array}$ & $\begin{array}{l}240{ }^{\circ} \mathrm{C} \\
230^{\circ} \mathrm{C} \\
300^{\circ} \mathrm{C}\end{array}$ & $\begin{array}{l}240^{\circ} \mathrm{C} \\
220^{\circ} \mathrm{C} \\
280^{\circ} \mathrm{C}\end{array}$ \\
\hline Acrinathrin retention time & $3.89 \mathrm{~min}$ & $10.34 \mathrm{~min}$ & $3.00 \mathrm{~min}$ \\
\hline $\begin{array}{l}\text { Detection limit: } \\
\text { from honey } \\
\text { from beeswax }\end{array}$ & $\begin{array}{l}0.01 \mathrm{mg} / \mathrm{kg} \\
0.10 \mathrm{mg} / \mathrm{kg}\end{array}$ & $0.01 \mathrm{mg} / \mathrm{kg}$ & $0.10 \mathrm{mg} / \mathrm{kg}$ \\
\hline
\end{tabular}

Table 2

Recovery rates in the course of determination of acrinathrin residues

\begin{tabular}{lcc}
\hline \multicolumn{1}{c}{ Sample } & Fortification level $(\mathrm{mg} / \mathrm{kg})$ & Mean recovery $(\%)$ \\
\hline Control honey & $0.05-0.20$ & $96.7(\mathrm{n}=5)$ \\
Control beeswax & $1.00-5.00$ & $88.3(\mathrm{n}=4)$ \\
\hline
\end{tabular}

The results of this residue determination trial serve as a basis for the registration and marketing authorisation of the veterinary product GABON PA 92 in Hungary. In the future, the investigations will be extended to residue tests of acrinathrin in samples taken from different locations and at different intervals after treatment. For health protection purposes and to maintain the exportability of Hungarian honey, further tests will be performed with acrinathrin and other active ingredients of bee acaricides (fluvalinate, flumethrin, amitraz). 
Table 3

Residue content of honey and beeswax samples taken from beehives treated with GABON PA 92 strips against Varroa mites

\begin{tabular}{|c|c|c|}
\hline \multicolumn{2}{|c|}{ Sample (no. of bee colony) } & $\begin{array}{c}\text { Acrinathrin residue content }(\mathrm{mg} / \mathrm{kg}) \\
<0.01\end{array}$ \\
\hline Honey & $\begin{array}{l}22 \\
34 \\
46 \\
56 \\
60\end{array}$ & $\begin{aligned}<0.01 \\
<0.01 \\
<0.01 \\
<0.01 \\
<0.01\end{aligned}$ \\
\hline Beeswax & $\begin{array}{l}22 \\
34 \\
46 \\
56 \\
60\end{array}$ & $\begin{array}{l}<0.10 \\
<0.10 \\
<0.10 \\
<0.10 \\
<0.10\end{array}$ \\
\hline
\end{tabular}

\section{References}

Bienefeld, K. and Pritsch, G. (1992): Kooperation zwischen Züchtern und zentrale Auswertung: Ansatze für eine erfolgreiche Zucht der Honigbiene. Die Biene 128, 443-447.

Büchler, R. (1993): Rate of damaged mites (Varroa jacobsoni) in the natural mite fall with regard to seasonal effects and infestation development. Apidologie 24, 492-493.

Hillesheim, E., Ritter, W. and Bassand, D. (1996): First data on resistance mechanisms of Varroa jacobsoni (Oud.) against tau-fluvalinate. Exp. Appl. Acarol. 20, 283-296.

Hoffmann, S. (1993): The occurrence of damaged mites (Varroa jacobsoni) in cage test and under field conditions in hybrids of different Carniolan lines. Apidologie 24, 493-495.

Milani, N., Vedona, G. della and Greatti, M. (1995): A bioassay to test the susceptibility of Varroa jacobsoni to pyrethroids. APIMONDIA Verlag, Bucharest, p. 192.

Rosenkranz, P., Rachinsky, A., Strambi, C. and Röstorf, P. (1990): Juvenile hormone titer in capped worker brood of Apis mellifera and reproduction in the bee mite Varroa jacobsoni. Gen. Comp. Endocrinol. 78, 189-193.

Szalai, M. E., Pacs, Zs. and Molnár, E. (1998): Examination of Gabon PA 92 in Varroa control (in Hungarian). Méhészújság 11, 21-22.

Tóth, Gy. (1998): Chemicals available for Varroa control (in Hungarian). Méhészet 4, 4-5.

Vesely, V., Malonova, D. and Titera, D. (1995): Acrinathrin, an effective varroacide and its residues in stores, honey and wax. Apidologie 26, 321-322.

Wallner, A. (1993): Mein Weg in der Varroaresistenzzüchtung. Bienenvater 114, 107-108.

Wallner, K. (1997): Der Weg zur rückstandfreien Imkerei Strategien aus der Sackgasse. Bienenvater 6, 9-13.

Woyke, J. (1989): Breeding of honey bees resistant to Varroa jacobsoni. Am. Bee J. 129, 11-23. 